\title{
11. The Articulation of Tradition in Timor-Leste
}

\author{
James J. Fox
}

\section{Introduction}

When The Flow of Life was published in 1980, it was intended to identify some of the distinctive features of eastern Indonesia and to shift perspectives on how the region was viewed. In that volume, Timor figured prominently. Six out of 14 comparative essays - seven, if one counts Rote within this area - were focused on Timor. Previous comparative efforts had been limited and were largely confined to the influential study by the Dutch anthropologist F. A. E. van Wouden. His work, Sociale Structuurtypen in de Groote Oost, in 1935-translated as Types of Social Structure in Eastern Indonesia in 1968 - was based largely on fragmentary materials reported by travellers, missionaries and government officers. While certainly perceptive in many of its particular analyses, the work advanced a single formal model that purported to provide the original underlying basis for societies in eastern Indonesia.

The Flow of Life challenged this model by presenting a diversity of social forms in eastern Indonesia and by convincingly representing the diverse conceptual bases of societies of the region. The Flow of Life was the first study of its kind to be based on substantial fieldwork. As the book claimed, it shifted focus from the study of models to the study of metaphors - the often highly poetic articulation of metaphors of life.

This book, Life and Land in Timor-Leste, follows a trajectory set out in The Flow of Life. Like The Flow of Life, all the papers in this volume are based on considerable fieldwork. This work is, however, more specifically focused and critically formulated to consider local polities in Timor-Leste and the way in which they have survived and adapted to the Indonesian occupation, the United Nations' presence and the present-day national development demands of an independent Timor-Leste.

Despite the great attention given to Timor-Leste over the past decade, few studies have sought to examine traditional social life as framed within particular traditional polities and in different rural areas. This book should therefore have 
a double impact - both theoretical and practical. It opens a new window on what is occurring in Timor-Leste. The initial question to ask of this volume is what comparative insights it provides and where do these insights lead.

\section{Traditional Timorese Discourse}

On Timor, traditions go deep. They are bound to the land-to specific places and to particular origins. Thus, the common comparative framework for all of the essays in this volume is their examination of Timorese traditional relations to the land and the significance of these relations. These relations - somewhat bewildering at times - are in fact the substance of life.

From these local attachments and sources of vested authority, a network of connections spreads throughout the island. Although Timorese traditions might be thousands of years old, these are not static. Engagement with the world involves continual adaptation and reinterpretation. This process has allowed the Timorese to both resist and assimilate. The capacity to do this, however, has never been properly realised by those who have come to change Timor.

The source of this capacity is a conception of the world embodied in a language of complementary categories, a discourse that constitutes a general rhetoric and a pervasive logic. This use of binary categories is most densely manifest in the ritual languages used in formal relations and in ceremonies, but the most critical of these categories are equally part of ordinary discourse. Many of the papers in this volume provide exegeses on these key categories.

The second chapter in this volume, Susana Barnes' 'Origins, precedence and social order in the domain of Ina Ama Beli Darlari', is a superb examination of various 'origin groups' that comprise a socially diverse community in Uato Lari. The chapter focuses on core origin groups, their ritual position among other groups that make up the local polity and the complex relationships among all these groups to particular tracts of land. The paper offers an exemplary exegesis of key complementary categories in Timorese discourse. While only a careful reading can do justice to Barnes' exegesis, I wish to highlight the main categories she examines.

The first categories she focuses on are the categories elder/younger (kaka/wari). Together, these terms define and, separately, they distinguish, relations within a descent group and among related descent groups. As a set, these categories collectively identify members of an origin group while individually each specifies a relative relationship to the other. 
Barnes recounts an ancestral dispute between an elder and younger brotherancestors of the Beli and Darlari origin groups - that resulted in an allocation of land and status whereby the younger brother became the 'lord of the land'. This position is described as 'rod of the land/rock of the land' (rea mumu, rea uato). The narrative of this dispute explains why, in this context, the category of 'younger' takes precedence over the category of 'elder'.

In addition to these categories, Barnes introduces the important categories of black and white - categories that both describe and differentiate the two most important sacred houses, the white and the black houses (uma buti/uma ita), of the Darlari, each of which has different ritual duties in supporting the lord of the land. As Barnes explains, in this context, 'white' takes precedence over 'black'.

Within Darlari, there are other categorical distinctions among those who 'guard the fields/guard the water' (lai bosa/lai wai): the Makaer Luli who watches over the sacra and the Kabo Rai who allocates access to the land. Both are involved in the performance of the rituals of 'rock and tree' (uato no kai).

Having described this core group, Barnes discusses the designation of other in-coming origin groups in terms of the ritual categories that define them and locate them on specific lands. This again involves the categories of black and white used to identify certain allied groups who are known as the "people of the white children/people of the black children'. Yet other binary categories are applied to another vassal group to whom land was granted in return for the obligation to protect the borders of the domain. This is described as 'guarding the people/guarding the land', and the warrior group to whom this task of gatekeeper was allocated is referred to as the 'door and gate' (ita mata/kai hene) of the domain. Yet another group was incorporated into the Darlari domain as 'wife-taker' to the Darlari who as 'wife-giver' became committed to a continuing 'wife-giver/wife-taker' (oa-sae/uma ana) relationship. In all of this, only the Darlari elders possess the full knowledge of the elaborate historical construction of their domain from its origins to the present or, as it is described in Naueti, the knowledge that extends from 'trunk to tip' (la'a-na/rae-na). This is a critical feature of their centrality for the whole of the domain.

Although brief and directed specifically to aspects of ritual duties within a single domain, Barnes' paper provides a clear indication of the importance of Timorese binary discourse and how it is used to establish meaning and relevance to social relations. Other contributions to this volume are equally illustrative of this allimportant discourse. This is particularly so in the case of the paper by Elizabeth Traube (Chapter 6). 
All of Elizabeth Traube's writings exemplify a profound understanding of the Mambai based on careful and considered assessment of their discourse. Her fieldwork was first carried out in the 1970s prior to the Indonesian occupation and she has returned for further long fieldwork in the Aileu area. Her paper in The Flow of Life, 'Mambai rituals of black and white', is a thoroughgoing exegesis of 'the complementary opposition of two categories of ritual action, the "white" (buti) and "black" (meta)'. Her intention in that paper was not to describe a particular ritual sequence but rather 'to provide an outline of the total system by considering the set of ideas which underlie all ritual performance' (1980:291-2). Her book Cosmology and Social Life: Ritual exchange among the Mambai of East Timor (1986) extended the analysis of her paper in The Flow of Life into what is, without doubt, the most thoroughgoing and subtle examination of the thought world of an East Timorese population.

Her paper, 'Planting the flag', in this volume is no less brilliant because it is able to explicate Mambai intellectual engagement in interpreting categories of the past to confront realities of the present. Again, it is not my intention to repeat her analysis but rather to highlight the complementary categories she focuses on-many of which are those that Barnes highlights as well.

Traube's core narrative also involves a dispute between an elder and a younger brother that results in the movement of all the ancestral sacra-disks, necklaces, drums and gongs - to a second ritual house. This creates a division between cult origin villages: Raimaus associated with the elder brother and Hohul associated with the younger brother. Raimaus is represented as the northern 'door' that leads south to the 'innermost' sanctuary at Hohul. In this context, various categories are linked by association within the ambit of Mambai ritual life. They relate to the most important matters of ritual life. These matters are described in similar terms to those of the Naueti. They pertain to matters of 'rock and tree' (hauta nor aia).

The alignment of the categories that define the relationship of Raimaus to Hohul, as set out in the discourse of the narrative that Traube recounts, is as follows.

$\begin{array}{ll}\text { Raimaus } & \text { Hohul } \\ \text { Elder } & \text { Younger } \\ \text { North } & \text { South } \\ \text { Outer } & \text { Inner }\end{array}$

This is not, however, the only use of the categories elder/younger (kaka/ali). These categories are also used to distinguish among the founding ancestors of the Mambai and thus differentiate between outsiders and insiders: rulers and ruled. Although the narrative involves a triad of founders, it is told from 
the vantage of the youngest and presented as a succession of separate dyadic relations. ${ }^{1}$ Like all such origin narratives, it must be told from 'trunk to tip' and, like other narratives, its 'tip', which continues to develop, can be relied upon to provide an explanation of the present.

According to the narrative, a first-born brother, $\mathrm{Au} \mathrm{Sa}$, who is associated with the dark arts of blacksmithing, wanders off to the west and disappears thereafter from the narrative. A last-born brother, Loer Sa, 'rinses white, bathes clean', takes all regalia and departs to become the ancestor of the Malaia who are epitomised by the Portuguese. This leaves the middle brother, Ki Sa, to represent the Mambai who occupy Timor and who remain 'with only rock and tree'.

As told in dyadic formulation, Ki Sa is elder; Loer Sa is younger. Only by seeking the return of some of the sacred regalia from his Malaia brother is Ki Sa able to restore order: 'heavy rule and weighty ban' (ukun rihu/badun mdeda). Eventually the Malaia descendants of Loer Sa return to rule as the Portuguese. By this narrative, the Mambai are seen to retain their ritual authority and the 'base or trunk of rule' (uku-fun), while the Portuguese or their Malaia representatives are accorded political power-the 'tip of rule' (fail tu uku-laun).

What is most notable in this telling is the association of complementary categories that it entails. These are different to the telling of the narrative of Raimaus and Hohul in that in this narrative, the elder takes precedence by association with the inside and ritual authority whereas the younger brother is the outsider with political power. As Traube explains, this contrast can also be represented by the complementary categories 'male and female'.

$\begin{array}{ll}\underline{\text { Ki Sa }} & \underline{\text { Loer Sa }} \\ \text { Elder } & \text { Younger } \\ \text { Inside } & \text { Outside } \\ \text { Trunk of rule } & \text { Tip of rule } \\ \text { Female } & \text { Male }\end{array}$

\footnotetext{
1 It is a common and perhaps critical feature of such origin narratives that they reduce triadic relations to separate dyadic relations. The Kemak of Marobo, for example, attribute the foundations of their community to three ancestors: the Dato Telu who divide power and authority among themselves but only after an initial breach and eventual reconciliation with the youngest (Renard-Clamagirand 1982:117-25). The two elder brothers are given 'hot' + 'male' identifications as opposed to the third brother who is considered both 'cool' + 'female'. Similarly, the Tana Ai of Flores recognise a triad of ancestors, two of whom travel together and eventually establish the domain of Wai Brama and are then reunited with their wayward third brother who travels separately (Lewis 1988:45-69).
} 
Significantly, when pressed to categorise the Indonesian occupiers and to differentiate them from the Portuguese as Malaia, the Mambai invoke the figure of $\mathrm{Au} \mathrm{Sa} \mathrm{-} \mathrm{the} \mathrm{neglected} \mathrm{'third'} \mathrm{member} \mathrm{of} \mathrm{an} \mathrm{original} \mathrm{triad} \mathrm{in} \mathrm{the} \mathrm{origin}$ narrative - to represent the dark ancestor of the Indonesians. By the logic of the narrative, their attempt to rule represented an extraordinary categorical reversal in which the 'eldest' as 'outsider' attempted to rule.

As Traube demonstrates, there is a logic and subtle flexibility to the use of complementary categories that make possible the formulation of different contentions within Mambai discourse. Attention to this discourse opens vistas to our understanding of local developments in Timor.

Implicit in the categories of this discourse are ideas of governance- a conception of relationships the fulfilment of which is appropriate to wellbeing. At its core, there is the distinction between ritual authority and political power: authority is represented as an inner unity, symbolically 'feminised', silent, immobile but implacable, whereas political power can be diverse, symbolically 'masculine', active and invariably clamorous (see Fox 2008).

\section{Common Timorese Categories of Discourse}

The main categories of Timorese traditional discourse are similar throughout the island but their context varies. Recognising context is crucial. The use of complementary categories produces a relational dimension to all discourse. Together, any set of complementarities defines a unity while each of its components distinguishes within that unity. Similar binary categories can occur in different contexts; they may be applied recursively and, most pertinently, their subtle reversal is significant (see Fox 1989). ${ }^{2}$

Judith Bovensiepen's paper, 'Opening and closing the land: land and power in the Idaté highlands' (Chapter 3), focuses on narratives of origin that establish authority over the land. Various key complementary categories are invoked. As she explains, Laclubar is central land (rai klaran) and as such it is conceived of as 'the navel of the land, the liver of the land' (larek usar, larek nau). In this conception, 'the west of Timor-Leste represents the tail of the land (Idaté: hiak) and the east the head (Idaté: ulun)'. Her paper, as a whole, is an exegesis on the Timorese ideas associated with the categories of 'opening and closing' in relation to land.

2 The use of complementary categories allows for the formulation of relational propositions. Such categories may be applied recursively at different levels and the elements in any set of complementary terms may be reversed. This is why, for any interpretation, context is crucial. This use of complementary categories occurs widely in eastern Indonesia. I have discussed its use in greater detail in Fox (1989). 
Similarly, Molnar's paper, 'Darlau: origins and their significance for Atsabe Kemak identity' (Chapter 5), examines a succession of origin narratives told from different perspectives beginning from the time when the sky and earth were joined and presided over by a 'Female Sun' and a 'Male Sun' (Lelo hine) Lelo mane). The amusing (and somewhat confusing) details of these narratives are counters in a contestation over precedence within and beyond the Kemak domain of Atsabe. They foster a set of relations based on the common categories of elder/younger ( $k a^{\prime}$ ara/aliri) and of wife-giver/wife-taker (nai hine/nai mane).

The various narratives that Molnar summarises are replete with binary categories but not all of these categories are of the same critical significance within the framework of Timorese discourse. A relatively small number of complementary categories function as 'operators' - propositional organisers that set out relations among other categories.

Some of these key 'operators' are the gender categories such as male/female; relative age categories such as elder/younger and, in some cases, first-born/ last-born; colour categories such as black/white or red/blue-green; directional categories such as east/west, north/south or inside/outside; various body categories such as right/left, head/tail or trunk/tip; conditional categories such as open/closed or hot/cool; and a number of verbs of placement such as lifting/ lowering or ascending/descending. Listing these categories as though they belonged to separate semantic domains is potentially misleading because of the overlap between them.

Perhaps the most important aspect of this discourse is its continuing use in assessing and reinterpreting current developments in Timor within a framework that relates the past to the present and is thus able to deal with a diversity of complex issues from land tenure to local governance. At the same time, this discourse is a tool for negotiating present, often contentious, relationships. It creates possibilities for achieving the resolution of problems based on reference to versions of the past that, depending on context, are accepted for present purposes. Moreover, traditions in Timor are flexible since they are not wedded to a single canonical view of the past but can draw on multiple perceptions of ancestral precedence.

Most important for understanding this traditional discourse is the recognition that the different populations of Timor who speak their own distinct languages share key 'operators' within this discourse. This would not be surprising among the related Austronesian languages of Timor. It is, however, remarkable that key elements of this discourse are also shared among non-Austronesianspeaking populations of the island. This is the particular significance of Andrew McWilliam's research among the Fatuluku. He has demonstrated this most 
explicitly in his paper 'Austronesians in linguistic disguise: Fatuluku cultural fusion in East Timor' (2007), but he does so as well in his paper, 'Fatuluku living landscapes' (Chapter 4), in this volume.

Although the Fatuluku use their own distinctive complementary categories, they also share various key categories with their Austronesian neighbours. Thus, they describe their wife-giving groups as 'trunk and stem' (ara ho pata); they associate the 'head of the land' (mua cao) with east and the 'tail of the land' (mua ulafuka) with west and they rely on elder/younger categories to distinguish siblings but also to differentiate ritually among the posts on which the house is constructed (McWilliam 2007). In some cases, as, for example, with the term for 'elder' (kaka), an Austronesian word has been borrowed to create the appropriate set of complementary categories. Indeed the very fact that terms are borrowed to establish common categories of discourse signals the fundamental importance of these categories.

This sharing of common categories of discourse points to a further congruence of social categories among the populations of Timor.

\section{The Congruence of Timorese Kin Categories}

The papers in this volume give some idea of the remarkable diversity of the forms of local social organisation on Timor. This diversity is found both within groups with the same language and across groups with different languages both Austronesian and non-Austronesian. Many of these differences are the result of a long history of adaptation and development including contact with neighbouring groups. Thus, as a result, there is, at an organisational level, a great variety of local practice that is distinctive and defining.

Despite this diversity, however, there is also a degree of commonality in kin relations. For example, all Timorese social systems are lineally organised and much of this lineal organisation across the island is based on similar categories. Thus, at a categorical level, father (F) and father's brother (FB) are equated but distinguished from mother's brother (MB) just as mother (M) and mother's sister (MZ) are equated and are everywhere, except among the Bunaq, distinguished from father's sister (FZ). This allows for the creation of 'lineally' organised groups_clans and lineages.

These clans and lineages might recognise either a maternal or a paternal lineality. The most striking case of this difference occurs among Tetun-speaking populations: the southern Tetun insist on maternal inheritance and descent whereas the northern Tetun and the Tetun in the east of Timor tend to rely on paternal inheritance and descent. The exception to this general rule are the 
Bunaq who distinguish father and mother's brother but do not distinguish between mother, mother's sister and father's sister. This 'incomplete' lineality has implications in the organisation and fluidity of social groupings among the Bunaq.

Table 11.1 presents the kin categories that are used across the whole of the island of Timor for the first ascending consanguineal generation. (It is essential to consider the whole of the island to appreciate the borrowing of specific relational terms among different populations.)

Virtually all Timorese populations use the term *ama for father and father's brother and *ina for mother and mother's sister. The only exceptions are at the eastern end of Timor. Unlike other non-Austronesian populations who have borrowed terms from their Austronesian neighbours, the Fatuluku use an entirely different set of terms for father and mother, mother's brother and father's sister to the rest of Timor. ${ }^{3}$

Table 11.1 Lineal Distinctions in First Ascending Generation

\begin{tabular}{|c|c|c|c|c|c|c|}
\hline Group & $\mathbf{F}=$ & FB $\neq$ & MB & $\mathbf{M}=$ & $\mathbf{M Z} \neq$ & $\mathbf{F Z}$ \\
\hline Rotinese & ama & ama & to'o & ina & ina & te'o \\
\hline Helong & ama & ama & baki & ina & ina & eto \\
\hline Dawan & amaf & amaf & bab mone & ainaf & ainaf & $\begin{array}{l}\text { bab feto } \\
\text { [Amanuban] }\end{array}$ \\
\hline N. Tetun & ama & ama & bab & ina & ina & ki'i [Fehalaran] \\
\hline S. Tetun & ama & ama & tua nai & ina & ina & ina feto [Wehali] \\
\hline Bunak & ama & ama & baba & eme & eme & eme \\
\hline Kemak & amar & amar & nair & ina & ina & ki'ir [Atsabe] \\
\hline Beka'is & ama & $\begin{array}{l}\text { amar kai } \\
\text { ama } \\
\text { [ama kai] }\end{array}$ & baba & $\begin{array}{l}\text { amar na'i } \\
\text { ina } \\
\text { [ina kai] }\end{array}$ & $\begin{array}{l}\text { inar kai } \\
\text { ina }\end{array}$ & $\begin{array}{l}\text { inar ki'i [Marobo] } \\
\text { ki'i }\end{array}$ \\
\hline Isni & aman & ama & banin & inan & inan & ki'in \\
\hline Tokodede & ama & ama & ama luli & ina & ina & $\begin{array}{l}\text { bagi hine [Liquisa] } \\
\text { ba'i [Maubara] }\end{array}$ \\
\hline Mambai & ama & ama & na'i & ina & ina & kai (hinan) \\
\hline Idaté & ama & ama & bani manek & ina & ina & bani mahinak \\
\hline Isni & ama & ama & lobak banin & ina & ina lobak & ki'in \\
\hline Galoli & ama & ama & ba'i & ina & ina & obu \\
\hline Naueti & amau & amau & obu & inau & inau & in'tua \\
\hline Waima'a & ba'a & ba'a & obu & woi & woi & in'tuo \\
\hline Makassae & baba & baba & boubo & ina & ina & ina hatu \\
\hline Fatuluku & palu & palu & pienu & nalu & nalu & tamu \\
\hline
\end{tabular}

3 The Waima'a, who are an Austronesian population now under heavy Makassae influence, appear somewhat anomalous in that they use the term woi for mother and mother's sister. They also happen to use another term, mama. Where the woi term comes from is not clear. 
At a deeper level, the evidence in Table 11.1 points to a time when all of the Austronesian populations of Timor were previously bilaterally organised. The diversity of terms for the categories mother's brother (to'o, baki, bab mone, baba, ba'i, tua nai, nair, banin, banin manek and obu) and father's sister (te'o, eto, bab feto, ki'i, inar ki'i, bagi hina, banin hina, kai and ina tua) suggests multiple separate processes of creation. From this perspective, the partial, incomplete transition of the Bunaq to lineality is not particularly anomalous. It could be argued as well that other Timorese societies - the Kemak, for example - are still undergoing this transition.

This evidence, combined with similar evidence from elsewhere in eastern Indonesia, links the Austronesian social formations found on Timor to earlier bilateral forms of Austronesian social organisation that are still evident in Taiwan and much of western Austronesia.

The present-day similarity in the configuration of kin relations on Timor and the family resemblance of key terms used in this configuration contributes to defining a common ground for social interaction. This is even more so if one extends this perspective to the primary kin categories that define relations between siblings and cousins.

On Timor, as elsewhere in eastern Indonesia, gendered terms for siblings are also applied to parallel cousins - the children of one's father's brother and mother's sister. Relative age terms distinguish siblings but are applied only between members of the same sex. Thus, brothers and male parallel cousins will refer to each other as elder or younger and sisters and female parallel cousins will do the same among themselves. Other terms will be applied between siblings and parallel cousins of the opposite sex.

This configuration of relationships is found throughout Timor with two minor variations on this system. The majority of Timorese populations use two terms to distinguish between elder and younger (as, for example, kaka/alin among the Mambai). The Tetun and those populations influenced by the Tetun, together with some but not all Kemak, the Idate and the Bunak, use three terms for relative age. These three give rise to two dyads. Thus, among the Tetun, brothers and male parallel cousins use the terms maun/alin for elder/younger, while sisters and female parallel cousins use the terms bin/alin for elder/younger. It is particularly instructive that the Kemak of Marobo who are in closer proximity to the Tetun and more particularly to the Bunaq ${ }^{4}$ use three terms whereas the Kemak of Atsabe who are at a greater distance from the Tetun and Bunaq retain a two-term (ka'ara/alin) configuration. Both the two-term and the three-term

4 The terms for relative age used among the Kemak appear to reflect borrowing from the Bunaq, their immediate neighbours. Thus, the Bunaq appear to have borrowed from the Tetun and the Kemak from the Bunaq. 
patterns of relative age are transformations of similar Austronesian two and three-term relative age patterns. What is significant on Timor is that the nonAustronesian-speaking populations - the Bunaq, Makassae and Fatuluku-have all borrowed from their Austronesian counterparts to create similar relative age configurations.

A minor variation on the Timorese pattern of relations among siblings and cousins is found among the Bunaq and the Naueti. Instead of using gendered terms between siblings and parallel cousins of the opposite sex, both societies rely on a single reciprocal term. In the context of eastern Indonesia, this is in no way unusual. The use of a single reciprocal term between opposite-sex siblings and parallel cousins is in fact a common pattern variant, particularly among Austronesian societies in Maluku.

\section{Table 11.2 Gender and Relative Age Distinctions in Ego's Generation}

\begin{tabular}{|c|c|c|c|}
\hline \multirow[b]{2}{*}{ Group } & \multirow{2}{*}{$\begin{array}{l}\text { Sibling/parallel cousin } \\
\text { (Same sex) } \\
\text { Elder/younger }\end{array}$} & \multicolumn{2}{|c|}{$\begin{array}{l}\text { Sibling/parallel cousin } \\
\text { (Opposite sex) }\end{array}$} \\
\hline & & Brother (w.s.) & Sister (m.s.) \\
\hline Rotinese & ka'a/fadi & $\mathrm{na}(\mathrm{k})$ & feto(k) \\
\hline Helong & kaka/pali & blane & bata \\
\hline Dawan & tataf/olif & nauf & fetof [Amanuban] \\
\hline N. Tetun & maun/bin/alin* & nan & feton [Fehalaran] \\
\hline S. Tetun & maun/bin/alin* & nan mane & fetosawa [Wehali] \\
\hline Bunaq & kaqa/nana/kauq* & \multicolumn{2}{|c|}{$g$-intili } \\
\hline Kemak & kaar/nanar/alir* & nar & mtor [Marobo] \\
\hline Kemak & ka'ara/aliri & nar & toporo [Atsabe] \\
\hline Beka' is & ka'an/walin & manek & fetok \\
\hline Isni & ka'an/alin & naran & haton \\
\hline Tokodede & bo/alin & na mane & moto hine [Liquisa] \\
\hline Tokodede & kaka/alin & na & moto [Maubara] \\
\hline Idate & bouk/bin/alin* & nara & hitoo \\
\hline Mambai & kaka/alin & nara & tbo \\
\hline Waima'a & wa'i/ware & bo'u & mae \\
\hline Naueti & kaka/wari & \multicolumn{2}{|c|}{ mae (ana) } \\
\hline Makassae & kaka/nook & $b o^{\prime} o$ & topo \\
\hline Fatuluku & kaka/noko & nami & lereno \\
\hline
\end{tabular}

These relationship categories are, as it were, the basic building blocks on which different configurations of social organisation on Timor are structured. Although these particular categories are similar to one another, they each occur in different overall configurations of social relationships - a wider kin terminology, thus allowing for a diversity of social organisation across the island. 


\section{The Dynamic of Unity and Division Among Uma Lulik}

Just as this volume provides critical insights into Timorese traditional discourse, it also provides valuable documentation on the resurgence of traditional institutions and practices. Few commentators expected this reaffirmation of local tradition to emerge after the decades-long disruptions of the Indonesian occupation and the devastations that occurred in 1999. In the first flush of freedom under UN auspices, attention was directed to the formulation of new forms of democratic governance. In this process, the rural populations of TimorLeste were left to reshape their own local identities and, remarkably, across the island, great emphasis was given to the rebuilding of traditional houses - what are generally referred to as uma lulik.

Restoration of uma lulik occurred throughout Timor-Leste at a remarkable pace. The anthropologist Alexander Loch, who began his fieldwork in the Baucau area in 2002, was one of the few outsider observers to attempt to document the building of uma lulik. In his book Haus, Handy \& Halleluia (2007), in which he examines the building of three such uma lulik, he estimates that between 1999 and 2004 in the area around Baucau alone, there were 150 to 200 uma lulik constructed or reconstructed. This number meant that there were 30 to $40 \mathrm{uma}$ lulik restored each year over the period he was able to survey (Loch 2007:291).

According to Loch, the physical construction of these houses required from two to five months' work and demanded at least 1000 man-days of laboursome needed twice this amount. The particularity of construction - the choice of timbers and other materials and the necessity that all work should follow a particular ritual order — was paramount.

Yet this considerable labour was not the main focus of effort. More important for the construction of any single uma lulik were the negotiation, re-establishment and celebration of the specific social relationships that underpinned the house as a ritual entity - as a named sanctuary and locus of identity. Loch notes that this complex negotiation to reconcile relationships among the living was mediated through ritual invocation and a precarious dialogue with the spirits of the ancestors of the parties involved.

An essential feature of every uma lulik is its name, its narrative of origins and thus its grounding in the past. Physical structures can be destroyed-and indeed were destroyed during the Indonesian occupation-but not the idea of these structures, embodied in name and origin. This was retained in local consciousness and was given re-expression as soon as circumstances allowed. 
In this volume, Traube's discussion of the importance of the relationship between the two origin villages Raimaus and Hohul gives a glimpse of the centrality of these structures within a larger orbit of relationships. Barnes' examination of relations among the various specifically named branch houses of the main 'origin' group of Darlari and their further relations with other migrant houses provides an even clearer indication that uma lulik do not exist as entities on their own but as a part of a nexus of relationships. Similarly, Molnar's discussion of the contentious efforts at the re-establishment of precedence within the domain of Atsabe through the renewal of relations between different constituent houses, each with their own ideas of precedence, points to the ever widening framework within which any particular uma lulik is located. Perhaps most telling of all is Palmer's contention in her paper, 'Water relations: customary systems and the management of Baucau City's water' (Chapter 7), that managing the town's water supply would be best achieved by a 'mapping' of the uma lulik within the watershed to determine and then to negotiate usage rights with ritual custodians.

Increasingly, the role of uma lulik can no longer be ignored in local governance. Their social prominence is apparent, even as their role in Timor-Leste continues to develop. It is instructive to see the way that members of urban communities are being drawn into participation in the ceremonies of their uma lulik of origin. A return to the countryside for celebrations is coming to be seen as a social obligation even for city dwellers. In particular, the generation of 1999- the so-called geração foun-especially those deeply influenced by education in Indonesia and overseas, have begun to rediscover their local 'roots' and are now more willing to link themselves with particular ancestral uma lulik. It is possible - indeed probable - that in the future, a link to an uma lulik will be an essential component of East Timorese identity.

From a sociological perspective, the resurgence of uma lulik is still in its early phase. As emphasised by virtually all of the papers in this volume, an uma lulik does not exist on its own but in relation to other uma lulik. As more uma lulik come into being, the connections between them are extended and articulated, making every ritual celebration of a house's origins a political event. This opens up another aspect of Timorese tradition: the tracing of paths between houses.

For all of the attention given to local relations, autochthony and the spirits of place, there is no paper in this volume that does not also point to the ambulatory nature of Timorese society. In the past, as in the present, individuals and groups are associated with particular paths across the landscape. Thus, for example, Sandra Pannell in her paper, 'Struggling geographies: rethinking livelihood and locality in Timor-Leste' (Chapter 10), emphasises the importance of the oral histories of mobility among the Fatuluku, and Antoinette Schapper in her paper, 'Finding Bunaq: the homeland and expansion of the Bunaq in central 
Timor' (Chapter 8), provides a detailed examination of Bunaq expansion. For individuals and groups, the tracing of pathways is part of the creation of social identity.

In her paper, 'Tensions of tradition: making and remaking claims to land in the Oecusse enclave' (Chapter 9), Laura Meitzner Yoder describes the nature of these 'paths'. She writes: 'Taboos (nuni) sometimes serve as a mnemonic device for the history of family migration. Hence, asking the history of a family's nuni array can evoke their geographic journey through various points, where events occurred and which taboos were acquired along the way.'

The term nuni, which Yoder translates as 'taboo', is the Dawan or Atoin Pa Meto equivalent of the Tetun term $\operatorname{luli}(k)$. Here Yoder notes that in their narratives of mobility, the Dawan evoke locations along a path of migration marked by events of ancestral significance. The formal invocation of these locations, which commonly occurs in ceremonies on Timor, constitutes a 'topogeny' (Fox 1997) - a recitation that functions much like a genealogy to locate individuals and groups within an ordered past.

The topogenies of different groups can intersect at different strategic locations, providing linkages similar to the linkages created by common ancestors. Key locations might be associated with physical features of the landscape but they might also be represented by houses or the remains of previous settlements. The reconstruction of uma lulik that are associated with significant locations and formative events thus come to mark out prominent paths in narratives of social mobility.

An uma lulik does not exist on its own but in relation to other uma lulik. Each uma lulik is part of a network. With the re-establishment of uma lulik, various local networks are being created and, as these networks expand, they are beginning to draw links to one another. Paths are being drawn within these networks, allowing groups and individuals to trace and create relationships that were previously obscure (or perhaps never before existed). Molnar, for example, notes that the Kemak network of Atsabe did not, at the time of her fieldwork, extend to embrace the Kemak of Marobo, but she is able to point out a connection between Atsabe Kemak and Marobo Kemak through the origin houses of the Atsabe-oriented villages of Boboe and Obulo. Connecting the Atsabe houses to houses in Boboe and Obulo and from these houses to Marobo creates a path that can then extend to the Bunaq with whom the Marobo Kemak are intermarried. Such paths are the makings of a new form of social integration for Timor-Leste. 


\section{Conclusion}

For more than a decade, overwhelming attention in Timor-Leste has been given to the creation of new modern democratic instruments and institutions of governance. Under UN auspices, this emphasis was understandable and appropriate. The consequence of this, however, is that less attention has been directed to understanding elements of tradition that serve and preserve Timorese social life. Often, as was the case during the Indonesian occupation, the persistence of tradition has been regarded as a limiting factor for the development of a modern nation-state.

Despite this emphasis, an increasing number of researchers, including a number of East Timorese, have pointed to the importance of tradition in shaping national consciousness and local-level governance. They, too, have also noted the conflict among 'paradigms' of governance and the administration of justice in TimorLeste (Babo-Soares 2003, 2004; Hohe 2002; Lutz and Linder 2004; McWilliam 2005, 2008; Traube 2007; Trindade 2008).

Writing on what he describes as 'local authority systems', McWilliam has stressed both the lack of attention given to different conceptions of governance and the lack of engagement between developing local social formations and state regulatory systems.

'Recognition and understanding of these local authority systems remains both undervalued and poorly understood particularly at the national level of government in Timor-Leste, but their vitality and relevance to local contexts and to the fundamental strength of the nation state is undoubtedly significant' (McWilliam 2008:179). ${ }^{5}$

The Timorese possess centuries-old conceptions of governance that, as I have tried to indicate in this chapter, they continue to articulate. The discourse phased in complementary categories that they rely upon to frame these ideas is both subtle and flexible. It has served to accommodate Portuguese colonial impositions and an Indonesian occupation and it continues its engagement with the present.

The effort to understand snatches of localised Timorese dialogue and thus tune into what is occurring among a majority of the population poses a challenge to policymakers. A first step in making this effort requires a change in attitude and calls for what the Timorese would call respeitu - a genuine respect for what is valuable in local traditions and a willingness to acknowledge this valued heritage in forging new, possibly unique, forms of social governance. One can only hope that this volume will serve to clear a path towards such respect.

5 This paper by McWilliam appears in a volume edited by David Mearns (2008) with other papers that touch on these same issues. 


\section{References}

Babo-Soares, Dionisio da Costa 2003, Branching from the trunk: East Timorese perceptions of nationalism in transition, Doctoral dissertation, The Australian National University, Canberra.

Babo-Soares, Dionisio da Costa 2004, 'Nahe Biti: the philosophy and process of grassroots reconciliation and justice in East Timor', Asia Pacific Journal of Anthropology, vol. 5, no. 1, pp. 15-34.

Fox, James J. 1980a, 'Models and metaphors: comparative research in eastern Indonesia', in James J. Fox (ed.), The Flow of Life: Essays on eastern Indonesia, Harvard University Press, Cambridge, Mass., pp. 327-33.

Fox, James J. (ed.) 1980b, The Flow of Life: Essays on eastern Indonesia, Harvard University Press, Cambridge, Mass.

Fox, James J.1989, Category and complement: binary ideologies and the organization of dualism in Eastern Indonesia' in David Maybury-Lewis and Uri Almagor (eds), The Attraction of Opposites: Thought and Society in a Dualistic Mode, University of Michigan Press, Ann Arbor, pp 33-56.

Fox, James J. 1997, 'Genealogy and topogeny: toward an ethnography of Rotinese ritual place names', in J. J. Fox (ed.), The Poetic Power of Place: Comparative perspectives on Austronesian ideas of locality, Department of Anthropology, Comparative Austronesian Project, Research School of Pacific and Asian Studies, The Australian National University, Canberra, pp. 91-102.

Fox, James J. 2003, 'Tracing the path, recounting the past: historical perspectives on Timor', in James J. Fox and Dionisio Babo Soares (eds), Out of the Ashes, ANU E Press, Canberra.

Fox, James J. 2008, 'Repaying the debt to Mau Kiak: reflections on Timor's cultural traditions and the obligations of citizenship in an independent East Timor', in David Mearns (ed.), Democratic Governance in Timor-Leste: Reconciling the local and the national, Charles Darwin University Press, Darwin, pp. 119-28.

Hohe, Tanja 2002, 'The clash of paradigms: international administration and local political legitimacy in East Timor', Contemporary Southeast Asia, vol. 24, no. 3, pp. 569-89.

Lewis, E. Douglas 1988, People of the Source: The social and ceremonial order of Tana Wai Brama on Flores, Foris Publications, Dordrecht. 
Loch, Alexander 2007, Haus, Handy \& Halleluia: Psychosoziale Rekonstruktion in Osttimor, IKO - Verlag für Interkulturelle Kommunikation, Frankfurt am Main.

Lutz, George and Linder, Wolf 2004, Traditional Structures for Local Governance for Local Development, University of Bern, Bern.

McWilliam, Andrew 2005, 'Houses of resistance: structuring sociality in the new nation', Anthropological Forum, vol. 15, no. 1, pp. 27-44.

McWilliam, Andrew 2007, 'Austronesians in linguistic disguise: Fataluku cultural fusion in East Timor', Journal of Southeast Asian Studies, vol. 38, no. 2, pp. 355-75.

McWilliam, Andrew 2008, 'Customary governance in Timor-Leste', in David Mearns (ed.), Democratic Governance in Timor-Leste: Reconciling the local and the national, Charles Darwin University Press, Darwin, pp. 129-42.

Mearns, David (ed.) 2008, Democratic Governance in Timor-Leste: Reconciling the local and the national, Charles Darwin University Press, Darwin.

Renard-Clamagirand, B. 1982, Marobo: Une société ema de Timor, Langues et Civilisation de L'Asie du Sud-Est et du Monde Insulindien 12, SELAF, Paris.

Traube, E. G. 1980, 'Mambai rituals of black and white', in James J. Fox (ed.), The Flow of Life: Essays on eastern Indonesia, Harvard University Press, Cambridge, Mass., pp. 290-314.

Traube, E. G. 1986, Cosmology and Social Life: Ritual exchange among the Mambai of East Timor, University of Chicago Press, Chicago.

Traube, E. G. 2007, 'Unpaid wages: local narratives and the imagination of the nation', Asia Pacific Journal of Anthropology, vol. 8, no. 1, pp. 9-25.

Trindade, José 'Josh' 2008, 'Reconciling conflicting paradigms: an East Timorese vision of the ideal state', in David Mearns (ed.), Democratic Governance in Timor-Leste: Reconciling the local and the national, Charles Darwin University Press, Darwin, pp. 160-88.

van Wouden, F. A. E. 1968, Types of Social Structure in Eastern Indonesia, R. Needham (trans.), Koningklijk Instituut voor Taal-, Land- en Volkenkunde, Translations Series Vol. 11, Martinus Nijhoff, The Hague. 